\title{
Selective Neuronal Expression of Green Fluorescent Protein with Cytomegalovirus Promoter Reveals Entire Neuronal Arbor in Transgenic Mice
}

\author{
Anthony N. van den Pol and Prabhat K. Ghosh \\ Department of Neurosurgery, Yale University School of Medicine, New Haven, Connecticut 06520
}

In simple nervous systems, identified groups of neurons can be studied in depth. To allow the same advantage in the mammalian brain, we have generated green fluorescent protein (GFP) transgenic mice in which only a few types of neurons are strongly labeled with a fluorescent molecule, which the neurons synthesize internally, allowing the cells, their dendrites, filopodia, and axons to be identified in both living and fixed CNS, in slices and culture. The same neurons, with GFP expression controlled by part of the major immediate early promoter of human cytomegalovirus (CMV), show GFP beginning early in development, from one generation to the next, allowing cellular and physiological studies of axonal and dendritic growth, fate mapping, anatomical connections, and synapse formation in identified neurons. The human CMV promoter sequence we used was different from that used in previous work with other reporter genes and gave a dramatically different pattern of expression. Two transgenic lines with the same CMV promoter

In lower animals with simpler nervous systems, single types of cells can be recognized and studied in living and fixed neurons, particularly during development. The elegant studies on axonal growth and neuronal development in grasshopper (Goodman and Spitzer, 1979; Keshishian and Bentley, 1983) and other species with simple systems, including Drosophila and nematodes, have benefited significantly from being able to identify repeatedly selected cells and their axons in related experiments. To allow some of the same advantages in the mammalian brain, we generated transgenic mice that have strong expression of a marker gene, green fluorescent protein (GFP), that is expressed throughout the processes in restricted subpopulations of neurons in the brain and spinal cord.

Viral vectors that express GFP have been used to label neurons, but some viruses have the problem of being potentially toxic, and virally induced GFP is generally transient (Moriyoshi et al., 1996). Biolistics works nicely to shoot GFP gene-coated particles into brain slices, but which cell expresses the gene is partially random, and biolistics does not work well with cultured cells (Lo et al., 1994).

In some previous experiments, the intensity of GFP expression

\footnotetext{
Received July 14, 1998; revised Sept. 9, 1998; accepted Sept. 28, 1998.

This work was supported by the National Science Foundation and National Institutes of Health Grants NS34887 and NS31573. We thank Y. Yang for excellent expert help with these experiments, and Drs. E. Mocarski and R. Flavell for helpful suggestions relating to CMV and transgenic mice.

Correspondence should be addressed to Anthony N. van den Pol, Department of Neurosurgery, Yale University School of Medicine, 333 Cedar Street, New Haven, CT 06520.

Copyright (C) 1998 Society for Neuroscience $\quad 0270-6474 / 98 / 1810640-12 \$ 05.00 / 0$
}

show similar anatomical patterns of expression in the present study. Strong GFP labeling was found in a subpopulation of mossy fibers that innervated parasagittal bands in the cerebellar cortex and olfactory axons that projected into the olfactory bulb, subsets of motoneurons and dorsal root ganglion cells, granule but not mitral cells of the olfactory bulb, and a group of neurons in the hypothalamic suprachiasmatic nucleus. A novel type of neuron was strongly labeled in the olfactory bulb external plexiform layer. In normal brains, CMV does not constitute a threat, but in the developing brain, CMV can cause debilitating neurodegeneration and death; studies using the CMV promoter aid in understanding the affinity of CMV that has been suggested for specific brain regions.

Key words: green fluorescent protein; development; cytomegalovirus; axon growth cone; cerebellum; spinal cord; olfaction; hypothalamus has not been particularly strong. This is a problem for experiments in which one needs to study axonal growth over an extended time period and needs to strongly label the neuritic arbor. Neurons that were genetically engineered to express the GFP gene continuously, both in vivo and in vitro, would be an asset in studies of neuronal growth and response to injury. We have generated such a system, as described below.

Transgenic mice expressing a histochemical label have provided an important tool for the identification of neurons in the CNS. The lac $\mathrm{Z}$ gene coding for bacterial $\beta$-galactosidase has been used with a number of promoters and works well to identify positive cells but requires histochemical reaction generally on dead cells (Forss-Petter et al., 1990; Jankovski and Sotelo, 1996; Paradies et al., 1996; Sekerkova et al., 1997). Furthermore, in most cases, the reaction product is restricted to the region of the cell body, making it of limited use for studies of axonal projections and dendritic architecture. An interesting alternate approach to study live cells has been to generate transgenic mice that express an enzyme, such as alkaline phosphatase, on the outer surface of live cells (Gustincich et al., 1997), but this still requires histochemical reaction to identify positive cells.

We have generated transgenic mice that express an enhanced form of the jellyfish GFP protein that has been codon-corrected (from jellyfish to human) and red-shifted (Phe64 to Leu and Ser65 to Thr) under control of part of the human cytomegalovirus major immediate early promoter (here referred to as CMV promoter). Previous reports have used other reporter genes to study viral promoters to determine the relevance of the promoter to selective patterns of viral infection in the brain (Kothary et al., 
1991; Koedood et al., 1995; Fritschy et al., 1996). Our transgenic mice show a strong expression of GFP in a limited subset of neurons, and the same cell types express GFP from one generation to the next. The axons of these cells are strongly labeled to their terminals. A benefit of expression limited to a small number of neurons is that this allows a focus on subsets of neurons that may behave similarly, whereas other neurons in the same region of the brain or spinal cord are rendered invisible. GFP can be detected in the living cell bodies and throughout the entire extent of the living or fixed axons.

The significant advantage of this transgenic mouse for studying neuronal development and physiology is that a small subset of neurons can be recognized and studied by virtue of their GFP expression in vivo and in vitro. GFP has no apparent physiological effect, and GFP-expressing cells look, behave, and develop the same as non-GFP cells. This strategy of using transgenic mice with strong GFP expression in a very restricted subset of neurons in the developing and mature brain should be a significant aid for addressing a number of questions.

\section{MATERIALS AND METHODS}

Neuronal transfection with GFP cDNA. We used a GFP cDNA variant (Clontech, Palo Alto, CA) that was shifted in the red direction (longer wavelength) and corrected from jellyfish (Chalfie et al., 1994) to mammalian codon with improved fluorescence (Chalfie, 1995; Heim and Tsien, 1996; Yang et al., 1996). Two amino acid mutations were used (Phe64 to Leu and Ser65 to Thr). Neurons from normal nontransgenic mice were transfected with a Life Technologies (Gaithersburg, MD) Cell Porator electroporator. The electroporator was placed on a Gyrotory Shaker rotary table to increase fluid motion in the cuvette and was used with a $60 \mu \mathrm{F}$ pulse at room temperature. Four million cells were placed in $0.4 \mathrm{ml}$ of buffer, together with $10-80 \mu \mathrm{g}$ of GFP cDNA. After electroporation, cells were gently centrifuged to remove the DNAcontaining supernatant and then plated on polylysine-coated coverslips. In other experiments below, neurons from GFP transgenic mice were used, which had the GFP sequence incorporated into their genome and did not require further labeling or transfection.

Preparation of the DNA transgene. The pEGFP-C1 plasmid vector from Clontech was propagated in Escherichia coli DH5 $\alpha$ in the presence of kanamycin $(30 \mu \mathrm{g} / \mathrm{ml})$. pEGFP-C1, a C-terminal protein fusion vector, contains an enhanced jellyfish GFP. The GFP is under the control of a strong major immediate early promoter from the human CMV promoter. The vector DNA was isolated and banded twice over a $\mathrm{CsCl}$-ethidium bromide gradient by equilibrium centrifugation. The purified vector DNA was digested with the restriction enzymes Nsi-1 and Mlu-1, with appropriate buffers. The Nsi-1- and Mlu-1-digested DNA was subsequently electrophoresed on a $1 \%$ agarose gel with tetraethylammonium buffer to isolate a $1.642 \mathrm{~kb}$ fragment containing the CMV immediate early promoter sequence ( -583 to +7 of the $\mathrm{CMV}$ promoter sequence), the enhanced GFP sequence, multiple cloning sites, and SV40 poly(A) signals.

DNA preparation for microinjection. The $1.6 \mathrm{~kb}$ DNA fragment containing the GFP coding sequence with the CMV promoter and SV40 poly(A) signal was purified from the agarose gel by the QIAquick gel extraction kit protocol from Qiagen (Hilden, Germany). The precipitated DNA was pelleted, washed, air dried, and then purified and concentrated by passing through a Schleicher \& Schuell (Keene, NH) Elutip-d column and then through three Millipore (Bedford, MA) VMWP01300 filters. After dialysis, the DNA was collected, and the concentration was determined by optical density and adjusted to $5 \mathrm{ng} / \mu \mathrm{l}$ with injection buffer. Before microinjection, the DNA was filtered through a $0.45 \mu \mathrm{m}$ Millipore SJHV004NS syringe filter.

Generation of transgenic mice. Fertilized mouse oocytes were isolated from the F2 generation of matings between female and male (C57B1/6 $\mathrm{XC} 3 \mathrm{H} / \mathrm{HEJ})$ mice. The purified DNA with a concentration of $1-2 \mathrm{ng} / \mu \mathrm{l}$ was injected into the fertilized oocytes. After microinjection, the oocytes that survived were transplanted to the oviducts of pseudopregnant B6C3 F2 strain of foster mothers. The transgenic mice expressing the GFP gene were identified by PCR from DNA isolated from tail biopsies by using GFP-specific forward and reverse primers. Tail tissue was digested with $500 \mu \mathrm{g} / \mathrm{ml}$ proteinase $\mathrm{K}$ in $700 \mu \mathrm{l}$ of buffer containing $50 \mathrm{~mm}$ Tris- $\mathrm{HCl}$,
$\mathrm{pH}$ 8.0, $100 \mathrm{~mm}$ EDTA, and $0.5 \%$ SDS at $55^{\circ} \mathrm{C}$ overnight with agitation. The DNA was precipitated from the aqueous phase by adding $0.1 \mathrm{vol}$ of $3 \mathrm{M} \mathrm{NaAc}, \mathrm{pH}$ 6.0, and $2 \mathrm{vol}$ of ethanol at room temperature. After pelleting, the DNA was washed with $70 \%$ ethanol to remove traces of phenol and SDS. The concentrations of the DNA from different samples were equalized after measurement of optical density.

In our studies of 45 potential founder mice, 15 incorporated the GFP sequence in their genomes. These 15 founder mice were bred, and their offspring was tested by a combination of PCR, analysis of brain sections for GFP in a fluorescence microscope, and examination of GFP expression in cultured neurons. Of these mouse lines, we focus on one that showed strong GFP expression and to a lesser extent on a second line. GFP expression is found in the same regions of the brain and spinal cord in five generations of these mice.

PCR detection of transgenic mice expressing GFP. Two synthetic oligomers, one forward primer 5'-TAA ACG GCC ACA AGT TCA GC-3' and one reverse primer 5'-TGT TCT GCT GGT AGT GGT CG-3' were made from GFP coding sequences and used for PCR amplification of transgenic mouse DNA templates. The PCR reactions were performed in $50 \mu \mathrm{l}$ with $50 \mathrm{ng}$ of transgenic DNA, each with $10 \mathrm{~mm}$ Tris, $\mathrm{pH} 8.3,50 \mathrm{~mm}$ $\mathrm{KCl}, 1.5 \mathrm{mM} \mathrm{MgCl}_{2}, 200 \mu \mathrm{l}$ each of dATP, dGTP, dCTP, and TTP, 50 ng each of forward primer and reverse primer, and $1 \mathrm{U}$ of AmpliTaq DNA polymerase. The PCR reactions were done as follows: denaturation at $94^{\circ} \mathrm{C}$ for $5 \mathrm{~min}, 94^{\circ} \mathrm{C}$ for $1 \mathrm{~min}, 55^{\circ} \mathrm{C}$ for $1 \mathrm{~min}$, and $72^{\circ} \mathrm{C}$ for $2 \mathrm{~min}$ for 40 cycles. For a positive control, PCR was also performed on the GFP DNA fragment (Nsi-1 plus Mlu-1 fragment), which was originally introduced into the oocytes to generate transgenic mice. A negative control without DNA was performed also. The PCR reactions were analyzed on a $1 \%$ agarose gel to look for positive transgenic mice. An expected DNA band migrating at $472 \mathrm{bp}$ position was observed in the positive control and in lanes containing GFP-positive transgenic mouse DNA but not in the negative control lanes.

$m R N A$ analysis of different tissues obtained from transgenic mice expressing GFP. A number of different tissues from two transgenic mice were harvested, and total RNA was extracted with TRIZOL (Life Technologies). Different tissues included several different brain regions and non-neuronal tissue. Approximately $10 \mu \mathrm{g}$ of total RNA was loaded from each sample for Northern blots. A GFP DNA fragment was used as a probe for Northern blots. A cyclophilin probe was used as a control for relative loading of each lane. After detection of GFP RNA, the Northern blot was stripped and probed again for cyclophilin (van den Pol et al., 1994).

GFP detection. The use of PCR to detect the GFP transgene was sensitive in this regard but did not establish that the protein was actually expressed. To determine which mice showed GFP expression during development of this transgenic line, we used unfixed fresh tissue sections of GFP transgenic mice. Sections were cut on a vibratome. Fresh sections worked well, except that cells that were cut open tended to leak GFP, which raised the background fluorescence; for this reason, we observed some fresh sections while perfusing with a HEPES buffer to wash out leaky GFP. In some cases, before death, we viewed deeply anesthetized mice under the fluorescent microscope or took whole pieces or parts of the brain or spinal cord for viewing. In addition, we also used tissue culture of brain cells from postnatal day 1 mice to determine which founder lines expressed the transgene. Four mice per litter were pooled, and neurons were plated on glass coverslips. If GFP-positive cells were detected in the next $3 \mathrm{~d}$, then the founder mouse of that line was used for subsequent breeding. If the cells were negative, the founder mouse was not used further.

Because GFP tended to leak out of unfixed cells that were cut during histological processing, particularly obvious in thinner sections, some mice were aldehyde-fixed. Under deep sodium pentobarbital anesthesia, mice $(n=12)$ were perfused with $4 \%$ paraformaldehyde, and the brains were removed and cut on a vibratome or freezing microtome into $30-40$ $\mu \mathrm{m}$ sections. GFP was still visible after fixation without immunostaining, although the relative intensity of fluorescence was decreased by the aldehyde. To overcome the aldehyde-mediated reduction in GFP fluorescence, a GFP antiserum (Clontech) was used with peroxidase immunocytochemistry to stain some sections. The primary rabbit antiserum was used at a 1:2500 dilution and was visualized with goat anti-rabbit IgG-biotin and then by avidin-biotin-peroxidase immunostaining using reagents from Vector Laboratories (Burlingame, CA), followed by treatment with diaminobenzidine and hydrogen peroxide, as described elsewhere (van den Pol, 1985). Only transgenic mice showed brown peroxidase labeling, and it was found in the same brain regions in which GFP 
fluorescence was found. Staining with immunoperoxidase allowed the long-term storage and analysis of sections from GFP transgenic brains and the potential for later use for electron microscopy.

GFP expression was detected and photographed with Olympus Optical (Tokyo, Japan) and Zeiss (Oberkochen, Germany) fluorescent microscopes. An inverted Olympus IX70 with a $150 \mathrm{~W}$ mercury arc lamp with a fluorescein filter set gave the best GFP signal. A Bio-Rad (Hercules, CA) 500 confocal scanning laser microscope with an argon laser was also used to examine thick tissue sections. Some of the photomicrographs presented here are digital images from photographic negatives scanned on an Eastman Kodak (Rochester, NY) slide scanner and printed on an Eastman Kodak 7700 or 8650 dye sublimation printer.

\section{RESULTS}

\section{Neuronal transfection}

Before generating transgenic mice, we examined intensity and distribution of fluorescence with GFP-coding DNA from different plasmids after transfection of primary neurons with electroporation in $>500$ cultures. Previous studies with cotransfection experiments have shown that GFP can be used as a reporter for neuronal genes transfected into non-neuronal cells in vitro (Marshall et al., 1995). We compared actin, immediate early CMV, and mouse prion promoters. GFP-coding DNA from several different plasmids were compared with lac Z-coding plasmids using the same promoters. Transfection with lac $\mathrm{Z}$ yielded nicely labeled neuron cell bodies but poorly labeled axons and distal dendrites. In contrast, transfection with plasmids containing the enhanced GFP gave the strongest signal, and GFP fluorescence was found throughout the cytoplasm, including in axons and dendrites (Fig. 1A). Neurons from all areas used, including mouse, rat, and human neurons from olfactory bulb, hypothalamus, hippocampus, cortex, and spinal cord, showed strong labeling. Glial cells were also labeled in transfection experiments (Fig. $1 B)$; because the glial cells divided in culture, the GFP label was diminished in daughter cells. We also used recombinant DNA from plasmids made in which GFP was tethered to the axonal protein tau, with the cDNA coding for tau inserted at the C-terminal end of GFP. Neurons transfected with the tau-GFP construct showed green label in some of their processes, but the intensity of labeling was less, and the distribution was restricted. Within single neurons, both long-branching axons and dendrites were less strongly labeled with tau-GFP compared with neurons transfected with GFP alone. Although the efficiency of any particular promoter for expression in transfected neurons may not parallel its efficiency in the brains of transgenic animals, based on the strong levels of expression and the widespread intracellular distribution of GFP with the CMV-GFP construct, we selected this construct to generate transgenic mice. Because the CMV itself appears to preferentially infect subsets of neurons in the brain (Ho, 1991), we reasoned that its promoter might behave similarly in transgenic animals and generate high levels of GFP expression in subsets of neurons.

\section{Transgenic mice with GFP expression in restricted populations of neurons}

Examination of the brains and spinal cords of transgenic mice revealed expression of GFP in restricted types of neurons from the olfactory bulb to the sacral spinal cord. GFP appeared to be expressed by similar types of neurons within any single region and appeared to be constant from one generation of mice to the next. We estimate that the number of types of neuron that expressed detectable GFP was $<3 \%$. GFP could be detected in freshly cut sections viewed in a fluorescent microscope or laser confocal microscope, or after fixation and immunoperoxidase staining.
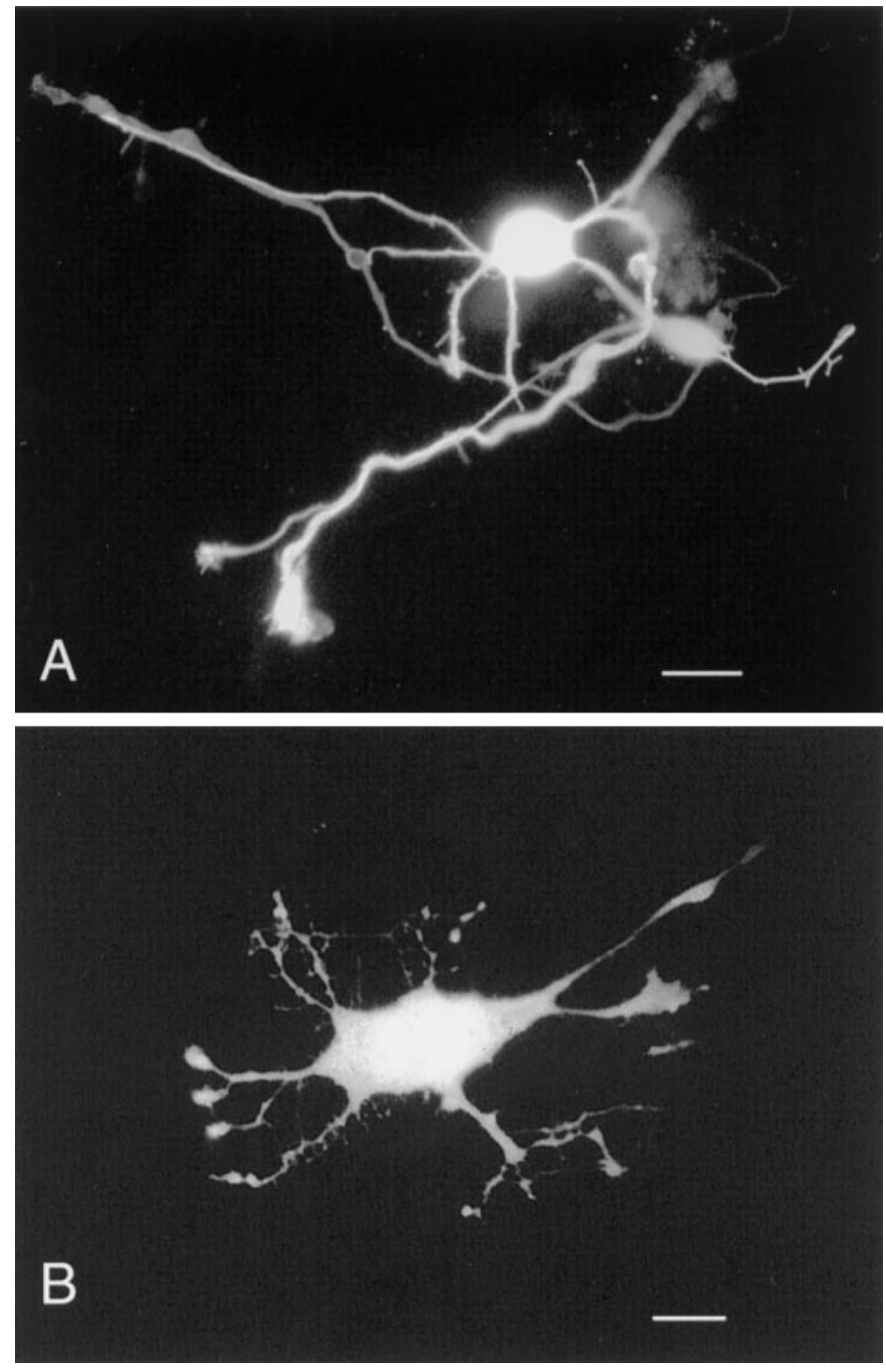

Figure 1. GFP transfected neurons. A, Two neurons with their neurites expressing GFP 2 d after transfection by electroporation. Scale bar, 12 $\mu \mathrm{m}$. $B$, A cell with the appearance of a glial cell is seen after GFP transfection. Scale bar, $10 \mu \mathrm{m}$.

Immunoperoxidase revealed cells and processes in the same regions as seen with fluorescent microscopy and allowed the use of differential interference contrast (DIC) microscopy, which facilitated detection of unlabeled cells in the background. Some types of neurons showed very strong expression that revealed the entire neurons, including the cell body (Fig. $2 A, C-E$ ), dendrites and their filopodia (Fig. $2 B$ ), and axons and their terminal boutons (Figs. $3 A-G, 4,5 A-C$ ). GFP-positive cells were found in the hypothalamic suprachiasmatic nuclei (data not shown); little labeling was found in the lateral hypothalamus. The large cells of reticular gigantocellularis showed GFP. In other regions of the brain, neurons were found with less robust GFP expression, such as in the CA3 region of the hippocampus, in a subpopulation of striatal neurons, and in the medial nucleus of the trapezoid body. Cells with the appearance of glial cells showed little GFP. In contrast, GFP expression via adenovirus introduction of the GFP gene into the CNS appeared to be found primarily in glial cells, although neuronal labeling was also noted (Moriyoshi et al., 1996). An asset of the approach we used is that GFP label is found not only in the cell bodies of living and fixed tissue, but it 

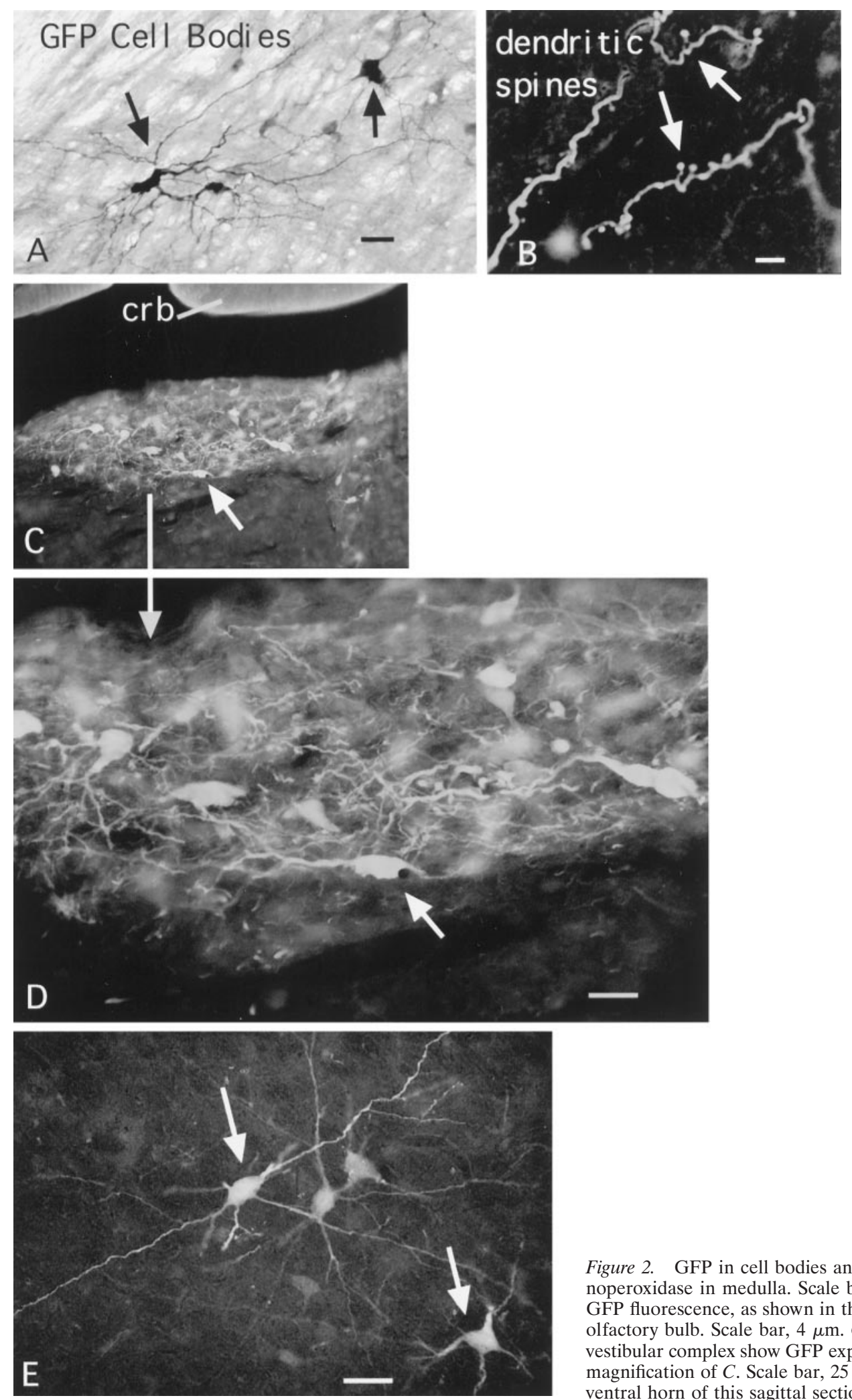

Figure 2. GFP in cell bodies and dendrites. $A$, Cells labeled with GFP immunoperoxidase in medulla. Scale bar, $20 \mu \mathrm{m}$. $B$, Long spine-like processes show GFP fluorescence, as shown in this example from the granule cell region of the olfactory bulb. Scale bar, $4 \mu \mathrm{m}$. $C$, Under the cerebellum $(c r b)$, neurons in the vestibular complex show GFP expression in cell bodies and dendrites. $D$, Higher magnification of $C$. Scale bar, $25 \mu \mathrm{m}$. $E$, In the spinal cord, motoneurons in the ventral horn of this sagittal section express GFP. Scale bar, $35 \mu \mathrm{m}$.

also can label distal axonal and dendritic processes. In previous studies of other transgenic mice which used different regions of the CMV promoter sequence, there was little or no detectable reporter gene in neuronal processes. This was attributable to the use of nuclear localization signals (Koedood et al., 1995; Fritschy et al., 1996), the use of lac Z rather than GFP (Baskar et al., 1996), and potentially to differences in the promoter sequence used in each study.

GFP was expressed in a group of $\sim 5-15 \%$ of the neurons in the dorsal root ganglia and in the axons from the DRG (Fig. $5 B$ ) that run rostrally up the dorsal columns of the cord (Fig. $5 C$ ). All dorsal root ganglia studied appear to have GFP-expressing neu- 

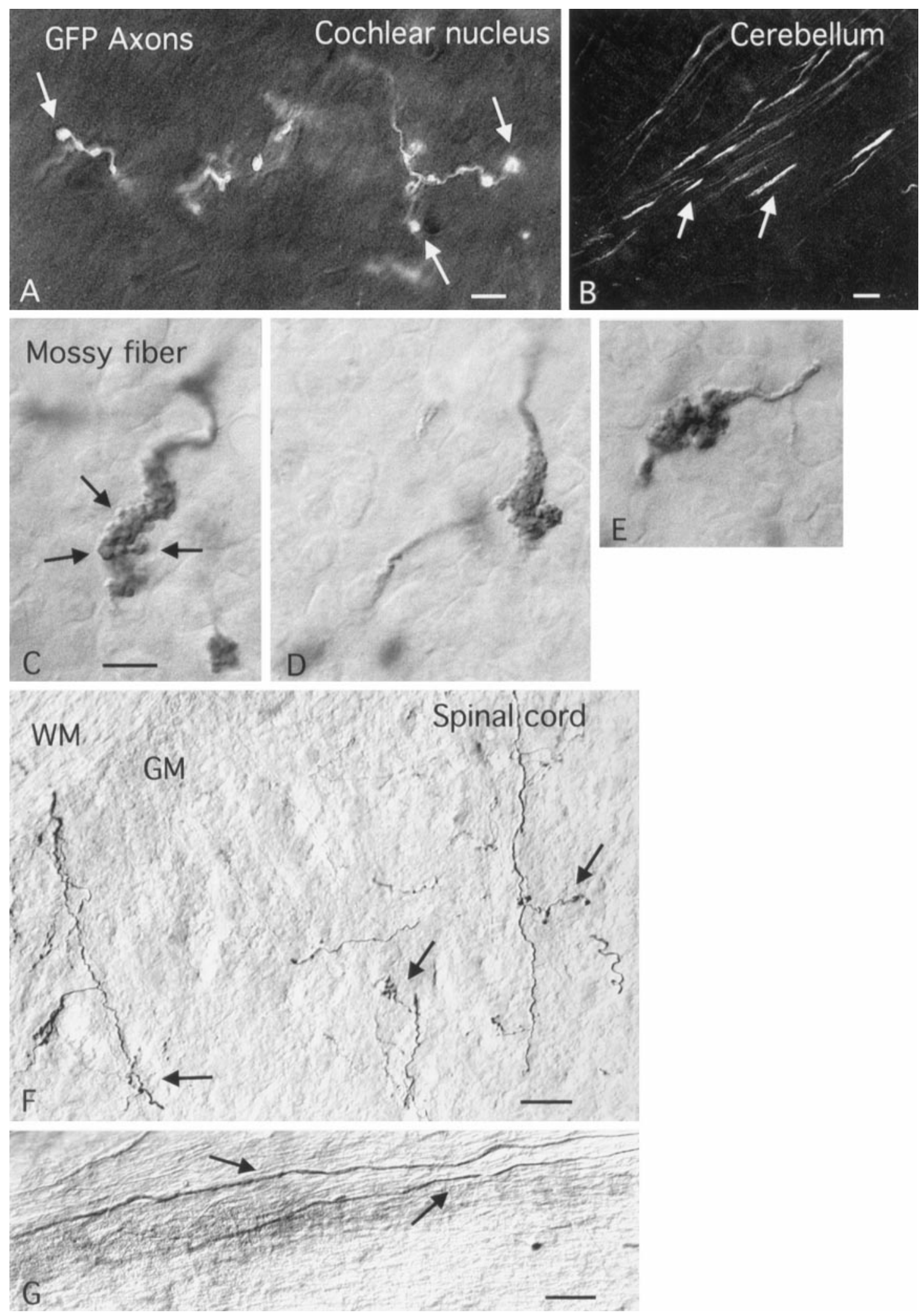

Figure 3. GFP in axons and their terminals. $A$, In the cochlear nuclei, some axons show strong GFP fluorescence and have terminal boutons. Scale bar, $2 \mu \mathrm{m}$. B, In the cerebellar cortex, GFP-expressing mossy fibers in the white matter enter the cerebellar cortex before spreading out to innervate the granule cell region. Scale bar, $10 \mu \mathrm{m}$. $C-E$, Mossy fiber terminals in the granule cell layer after GFP immunoperoxidase staining. Background visualization of granule cells is aided by DIC microscopy. $C$, Arrows show moss-like shape typical of these fibers. $D$, A later generation of transgenic mice shows a similar expression of GFP in the mossy fiber. $E$, A different line of transgenic mice with the same CMV promoter sequence as in $C$ and $D$ shows the same patterns of labeling, as shown here by the labeled mossy fiber. Scale bar (in $C$ ): $C-E, 5 \mu \mathrm{m}$. $F$, In spinal cord, fibers make terminal boutons (arrows) in the gray matter $(G M)$ after leaving the white matter $(W M)$. Scale bar, $9 \mu \mathrm{m}$. $G$, In dorsolateral cervical spinal cord white matter, long axons can be followed for many millimeters. Scale bar, $5 \mu \mathrm{m}$. 


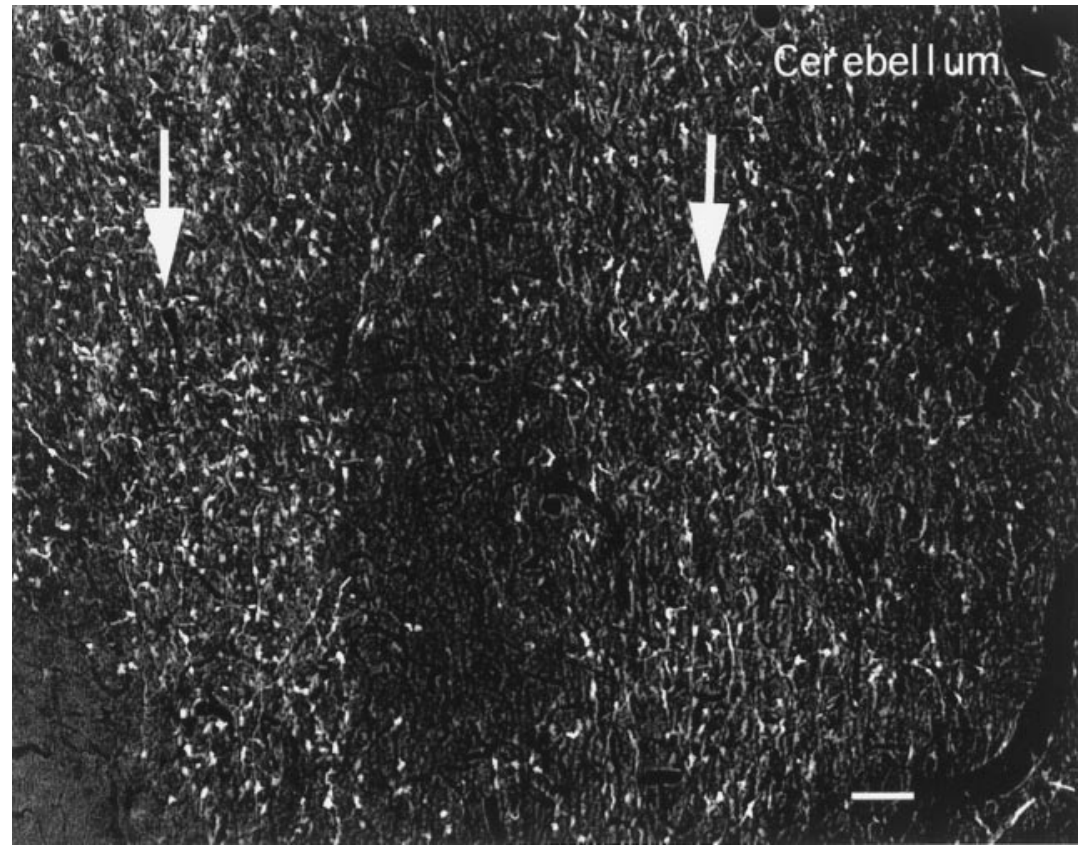

Figure 4. Parasagittal bands of GFP in cerebellar mossy fibers. In this low-magnification micrograph, GFPexpressing mossy fibers are found in parasagittal bands (arrows) in this coronal section of the cerebellum. Only mossy fibers are labeled here. Scale bar, $35 \mu \mathrm{m}$. rons. Some large, strongly fluorescent neurons were found in the ventral horn in motoneurons (Fig. $2 E$ ). GFP was detected in the dorsal columns of the intact in situ spinal cord and in the associated dorsal root ganglia and dorsal root (Fig. 5B) when deeply anesthetized mice were placed on a microscope before fixation perfusion. Axons were found in the white (Fig. $3 G$ ) and gray (Fig. $3 F$ ) matter. To demonstrate that GFP was expressed in experimental damaged spinal cord axons, we cut the right side of the dorsal columns of 8 -week-old transgenic mice with a shallow penetration of a number 11 scalpel blade into the thoracic spinal cord. Five days after sectioning, the ascending part of GFPexpressing DRG axons in the dorsal column showed small lateral GFP fluorescent filopodia, suggestive of growth (Fig. 5C) not commonly seen in control cord. This indicates that GFP expression in the axons of the spinal cord of the transgenic mice may be useful for studying axonal responses to injury.

The olfactory bulb showed the highest level of GFP expression within the brain. In Northern blots examining GFP mRNA expression, the olfactory bulb showed a higher level of GFP expression than any other brain or nonbrain tissue (Fig. 6). The expression was restricted primarily to the small inhibitory cells of the bulb that are immunoreactive for the transmitter GABA. Most granule cells showed GFP expression. In addition, juxtaglomerular cells showed GFP expression. Other cells of the bulb, particularly the excitatory mitral or tufted cells, showed no GFP. Some of the olfactory glomeruli showed strong expression (Fig. 7B), and others showed weak expression (Fig. $7 B$ ). This suggested that subpopulations of olfactory receptor cells that terminate in the glomeruli expressed GFP. This was consistent with patches of olfactory axons showing GFP and olfactory receptor cells in the olfactory mucosa expressing GFP (Fig. 7C).

The strongest expression of GFP in the bulb was found in an unusual type of cell in the external plexiform layer (EPL); cell bodies were found from the most external part of the granule cell layer through the EPL (Fig. 7A). These cells had dendritic arbors with one to four primary dendrites, which divided two or three times and remained in the EPL or near the external zone of the EPL. Many long spine-like appendages arose from the dendrites and ended in small swellings. The cell body of these cells was larger than that of typical granule cells and had an axon arising from the cell body and going in a direction toward the granule cell layer, suggesting these were not displaced granule cells that have no axon. A common cell of the EPL is the tufted cell, but that cell does not have dendritic spines, and the tufted cell dendrites enter the glomerular layer and form a distinctive tuft (Mori, 1987; Shepherd and Greer, 1990) not seen in the GFP-labeled cells. Another type of cell in the EPL is the van Gehuchten cell (Shipley et al., 1995). These cells contain vasoactive intestinal polypeptide, peptide histidine isoleucine, and other antigens (Sanides-Kohlrausch and Wahle, 1990; Alonso et al., 1993). However, descriptions of these van Gehuchten cells suggest they have local axon collaterals in the EPL and do not appear to have extensive dendritic spines, unlike the cells described here. Thus, the strongly GFP-positive cells in the EPL do not fit into any clear description of previously characterized neurons here.

Little GFP was found in the cell bodies of the cerebellar cortex. However, GFP was found in a subset of mossy fibers (Fig. $3 B$ ) and their terminals (Fig. $3 C-E$ ), originating outside the cerebellum, that provide excitatory innervation to the granule cells. Not all mossy fibers were GFP-positive, indicating that only a subset of the neurons that send mossy fiber projections to the granule cells expressed GFP. In coronal sections, GFP-expressing mossy fibers were found in parasagittal bands (Fig. 4), particularly obvious in the vermis. Mossy fibers are unique axons that make large terminal endings covered with small moss-like short appendages, and these showed robust GFP expression (Fig. 3C-E). Climbing fibers, the other primary excitatory afferent input to the cerebellar cortex, did not express GFP. The description here is not an exhaustive survey of all neurons that express GFP in these transgenic mice but instead delineates some of the major groups and serves as an overview.

In a second transgenic line made with the same CMV-GFP construct, the distribution of GFP-expressing neurons was similar to that described above, and the relative intensity of GFP expression in positive neurons was also parallel. An 


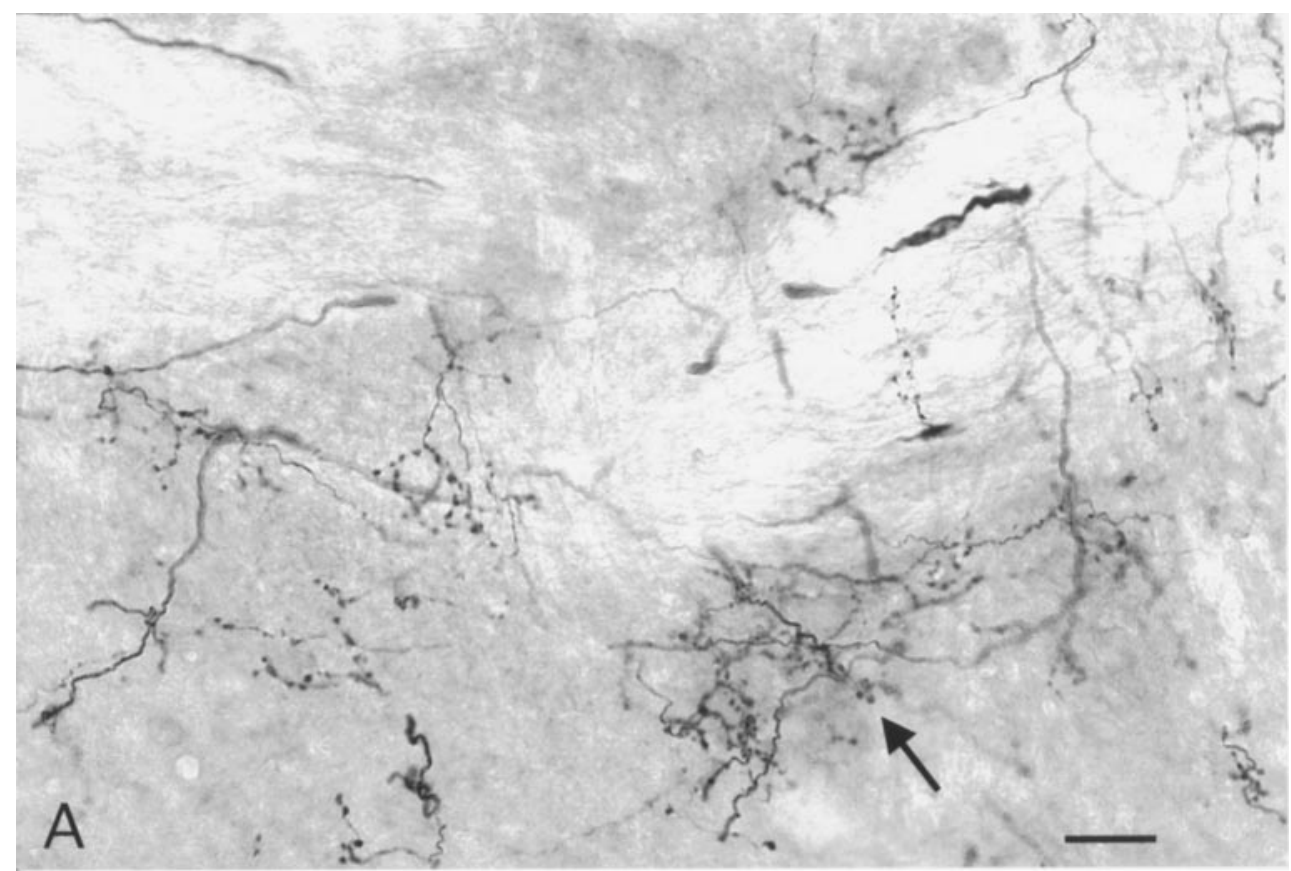

Figure 5. GFP in axons. $A$, In a sagittal section of the midbrain, GFP-containing axons detected with immunoperoxidase have many labeled terminal boutons. No cell body labeling is seen in this area. $B$, In the living dorsal root, GFP fluorescent axons emerging from the DRG (right) are found (arrows). Scale bar, $4 \mu \mathrm{m}$. $C$, Five days after spinal cord dorsal column damage in the transgenic mouse, ascending GFP axons in the dorsal column begin to show small filopodia. GFP axon is immunostained with peroxidase in this horizontal section of midthoracic spinal cord. Scale bar, $4 \mu \mathrm{m}$.
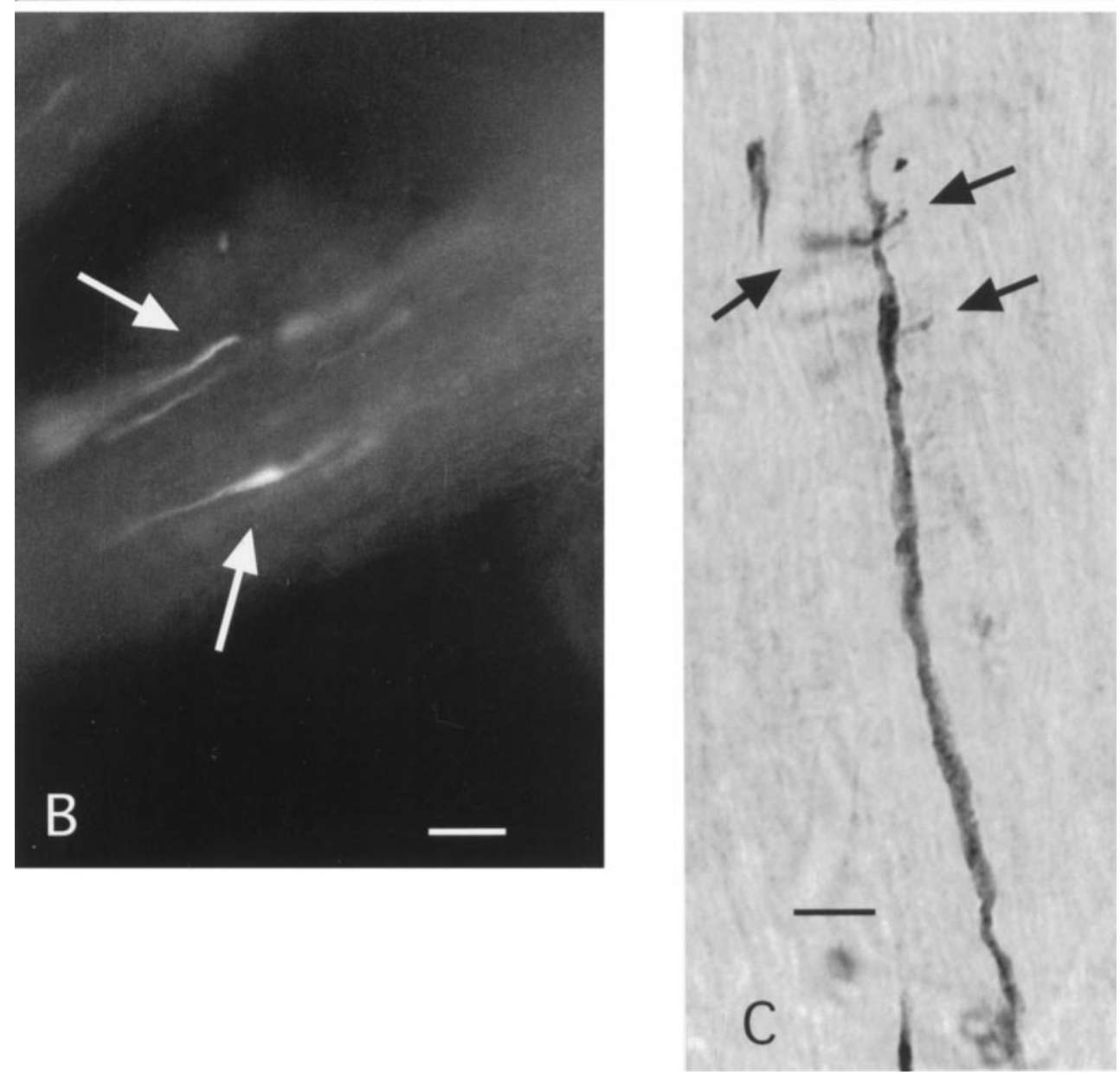

example of this staining in the second transgenic line is the absence of positive GFP cell bodies in the cerebellar cortex but the expression of GFP in cerebellar mossy fibers (Fig. 3E). Each line showed some variability between animals in levels of expression.

\section{Developing brain}

The level of GFP expression was stronger in developing brains that in adults. GFP expression was well developed in embryonic brains (data not shown). This is parallel to the high infection rates 


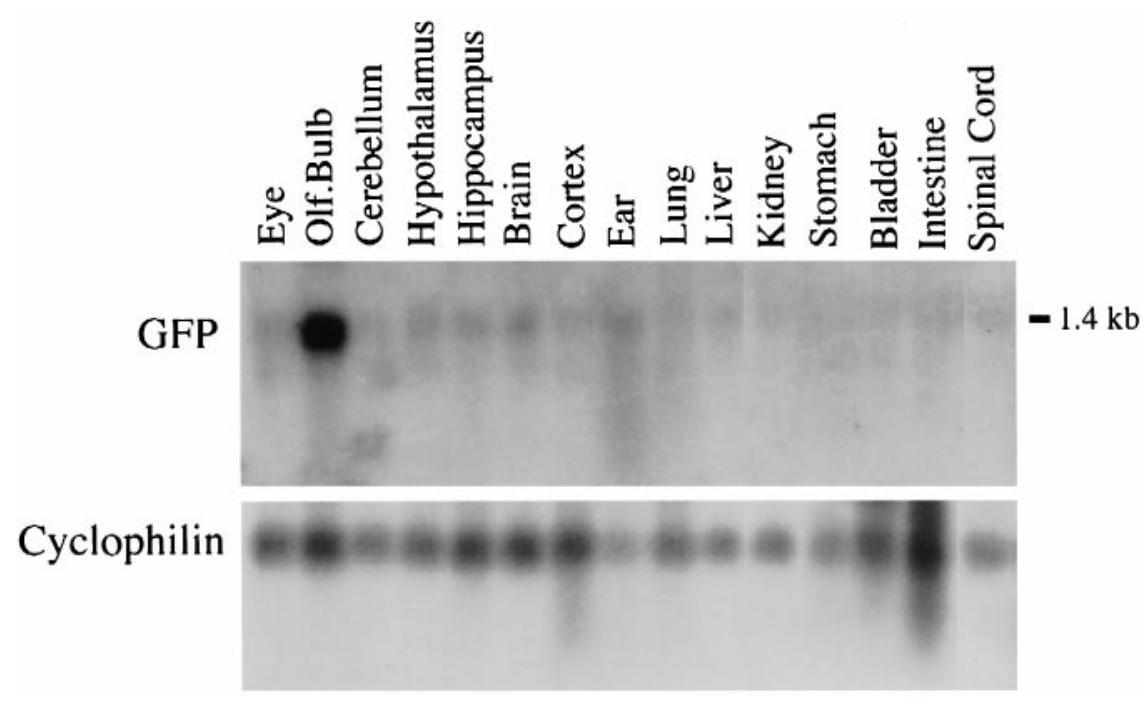

Figure 6. Northern blot of GFP expression. RNA was extracted from various tissues of transgenic mice and probed on a Northern blot for GFP. The highest level of expression was in the olfactory bulb. Other brain regions showed lower levels of expression. Brain refers to the remaining brain after the other regions in the blot were removed. After stripping, as a control, the blot was probed with cyclophilin to demonstrate the general level of RNA loading in each lane.

of the virus in the developing brain compared with the adult and supports the idea that the CMV (immediate early) promoter may be maximally activated in developing neurons. Embryonic day 18 and postnatal day 1 brains still in the head were sectioned and examined with or without immunostaining with GFP antisera. The strongest expression in these animals, as in adults, was found in the olfactory system in which early granule cells and juxtaglomerular cells expressed GFP, and olfactory receptor cells in the mucosa, together with their axons projecting into the bulb, were also labeled (Fig. $7 C$ ). In other regions of the brain in which positive neurons were found, the level of expression appeared higher at earlier stages of development.

\section{Tissue culture of neurons from GFP transgenic mice}

Different regions of brains or spinal cords from GFP transgenic mice were cultured. In strongly expressing transgenic cells in vitro, the GFP fluorescence was very bright and could be seen easily by eye, even with a $10 \times$ microscope objective. Because GFP does not easily fade and is remarkably stable, even during photoactivation, labeled living cells could be drawn with a camera lucida, photographed (Fig. 8), and then returned to the incubator. The entire axonal and dendritic arbor of single neurons could be clearly visualized. This was verified by examining single neurons growing on a glass substrate and by comparing the GFP fluorescent image with video-enhanced DIC microscopy. Every part of the neuritic tree that could be seen with the DIC image was also fluorescently labeled. Furthermore, there was no decrease in the intensity of fluorescence from proximal to distal, demonstrating that the entire neuritic tree was labeled with GFP. Both dendritic and axonal processes were well labeled, including their filopodia, lamelipodia, and terminal boutons. In developing neurons, both dendritic and axonal growth cones were clearly labeled. GFP expression was detected in positive cells as soon as they were plated. Regions of the brain, such as the olfactory bulb, with high number of positive cells also showed large numbers of positive cells in culture, whereas negative brain regions, such as the cerebellar cortex, did not. Immunostaining with Alexa 546 [a red fluorescent immunolabel from Molecular Probes (Eugene, OR)] showed glutamate decarboxylase immunoreactivity (antisera from Dr. W. Oertel) (van den Pol, 1985) in the GFP-expressing cells of cultured olfactory bulb neurons, consistent with the GABAergic identity of the transmitter of granule cells and the location of GFP-expressing cells in tissue sections of the olfactory bulb.

\section{DISCUSSION}

\section{Potential use of transgenic mice with selective GFP expression}

We demonstrate here that GFP is expressed selectively by subsets of neurons in the brain and spinal cord in adult and developing brain. In cells that strongly express GFP, their entire dendritic and axonal arbor is labeled. The potential advantage of this approach to labeling neurons is that in each generation the same neurons and their processes are labeled, allowing ongoing physiological and structural studies. Developing mice expressing GFP selectively in subpopulations of neurons may also be helpful for determination of cell lineage and fate maps of dividing cells during development. In parallel, the development of growing axons can be studied during development and after injury, in both fixed and living tissue. Cells that express GFP in situ also express GFP in vitro, allowing recognition of specific subsets of green cells in culture, of potential importance for characterization of the electrophysiology or single cell molecular biology of identified cells. Neurons expressing GFP are also ideal for transplantation studies in which both the cells and their processes could be followed in the non-GFP host brain. Finally, as described below, slight changes in the CMV (immediate early) promoter sequence may allow other populations of neurons that do not express GFP in the present study to generate high levels of GFP in other transgenic mice.

To study axons, their growth, and response to injury, the axon must be visualized. This can be achieved by applying a dye, such as DiI, to the outside of the cell, and this works well in some experiments; however, these dyes are often not strong enough to label thin distant axon terminals for extended periods (Liljelund et al., 1994). Alternately, labels such as neurobiotin or biocytin (Horikawa and Armstrong, 1988), or fluorescent molecules, such as fluorescent dextran, can be injected by a micropipette directly into a cell, labeling the entire dendritic arbor and axon trajectory. Although biocytin works well to label the entire cell, the process is labor-intensive, because the cell must be injected, fixed, and the stained, and labeled processes cannot be visualized while alive. Injection of fluorescent molecules works well for short time 

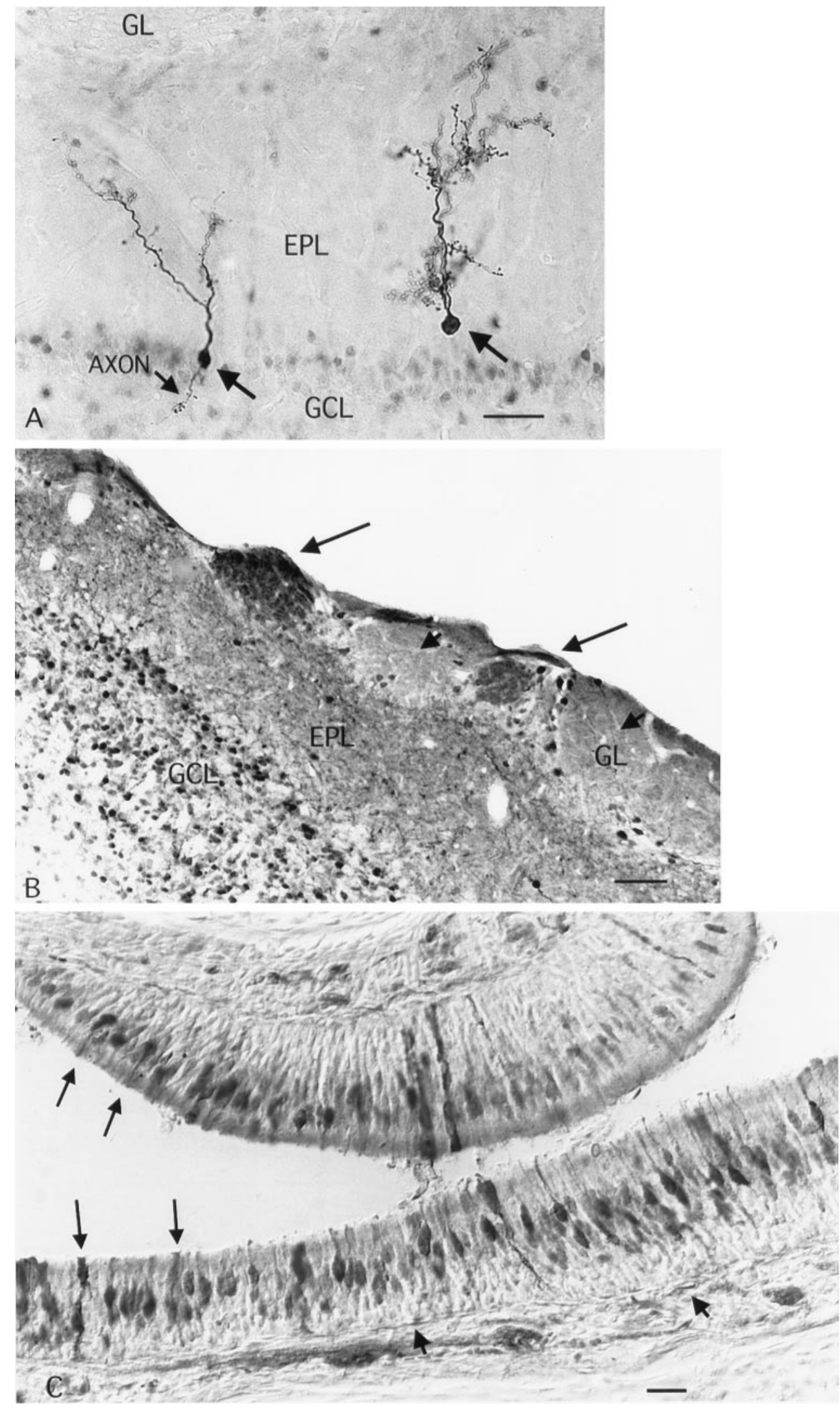

Figure 7. Olfactory bulb GFP. $A$, In the olfactory bulb, two unusual neurons (large arrows) showing strong GFP expression were immunostained with GFP immunoperoxidase. Axons (small arrow) can sometimes be followed from the cell body down into the granule cell layer. GL, Glomerular layer; EPL, external plexiform layer; GCL, granule cell layer. Scale bar, $35 \mu \mathrm{m}$. $B$, In olfactory bulb, some glomeruli (long arrows) show strong GFP immunoperoxidase. Other glomeruli (short arrows) show little staining. Scale bar, 70 $\mu \mathrm{m}$. $C$, In the olfactory mucosa of a developing mouse on the day of birth, some olfactory receptor cells, together with their sensory dendrite and efferent axons (small arrows), show GFP expression, consistent with the labeling of some glomeruli shown in $B$. Unlabeled background cells are seen with DIC microscopy. Scale bar, $15 \mu \mathrm{m}$.

genic mice with strong GFP expression, axons are well labeled over long periods of time, and even filopodia on growing axons and terminal boutons on mature axons are strongly labeled, attributable, in part, to the ongoing synthesis of the GFP mole- intervals, but the dye is usually degraded after a few days or sequestered in lysosomes and no longer labels the entire neuritic tree. Some dyes, such as Lucifer yellow, may even be toxic to the cell when viewed under fluorescent light. In contrast, in trans- 


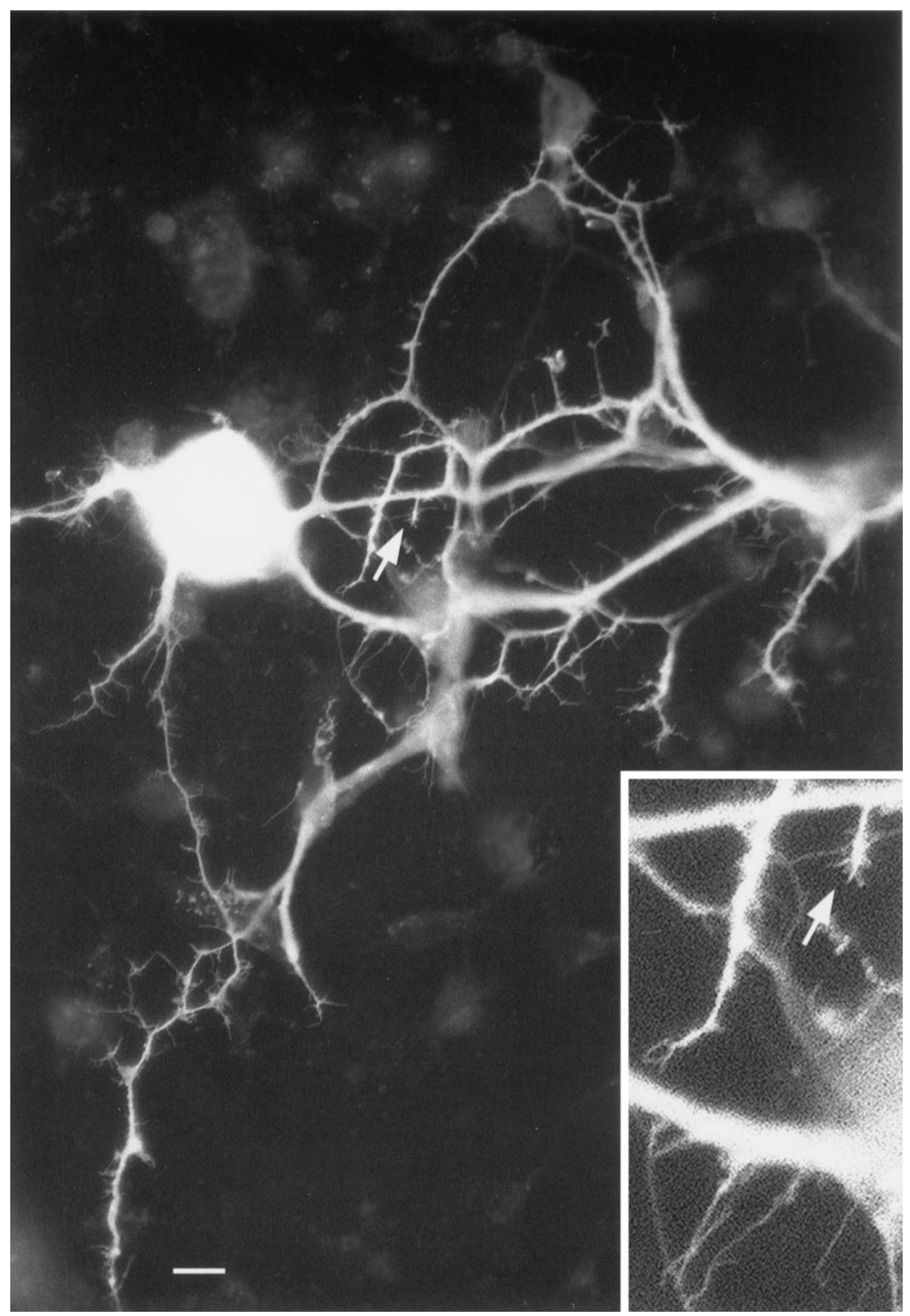

Figure 8. GFP in cultured spinal cord neurons. After $4 \mathrm{~d}$ in vitro, a few neurons show strong GFP expression, even at their smallest filopodia. Inset, Arrow shows same small growth process. GFP fluorescence is found in cell bodies and all processes. Other cells in the same field show little fluorescence. Scale bar, $6 \mu \mathrm{m}$. 
cule. Furthermore, because only small subsets of neurons are labeled, individual live or fixed axons and dendrites can be followed in their entirety because of the transparency of cells that do not express GFP, which constitute the great majority.

The GFP transgenic mice described here can be crossbred with one of the many interesting mutant mice that have been used previously for studying development, particularly in the cerebellum (Rakic, 1979). Because our transgenic mice have strong GFP expression in subsets of mossy fibers that innervate select parasagittal regions of the cerebellum, crossing these with mutants that have intrinsic defects in cerebellar development may prove a useful model for studying specificity of axonal target recognition. In parallel, crossing our mice with knock-out or overexpressing transgenic mice may provide a window for studying the contribution of specific genes involved in axonal growth of specific circuits that express their own label in living and fixed tissue.

When a label is introduced into the brain, either via direct injection, chemical manipulation, or viral mediation, the cells labeled may vary from experiment to experiment. In contrast, in the transgenic mice, the same populations of cells are labeled from generation to generation. Importantly, the CMV promoter is expressed at very early stages of brain development (Kothary et al., 1991; Koedood et al., 1995), allowing studies of cell division, migration, and process outgrowth in identified cells in the mammalian brain.

\section{CMV immediate early promoter}

CMV is a virus that probably infects the majority of adult humans (Ho, 1991). In most cases, it remains latent and accounts for little debilitation. In striking contrast, in the developing human brain, CMV infection can be disastrous. Early human brain infection with CMV, found in several thousand infants born each year, can lead to microencephaly, deafness, retardation, and seizures (Saigal et al., 1982; Ho, 1991; Perlman and Argyle, 1992). Similar problems in infected adults are not found unless the immune system is compromised, as with HIV infection (Nelson et al., 1988; Wiley and Nelson, 1988), and then CMV has been considered to be a significant threat. One factor that leads to the greater CMV problem in developing brains has been attributed to the fact that the immune system is not sufficiently developed to counteract CMV spread. Another factor is that developing neurons may allow higher levels of expression of the CMV promoter. The major immediate early CMV promoter drives the expression of two early CMV genes that set the stage for viral replication; enhanced expression of the promoter in developing neurons may constitute an additional mechanism for the greater debilitation found in developing humans. This concept is supported by the results from both the present paper and other works (Kothary et al., 1991; Koedood et al., 1995), showing that the CMV promoter is most active in early development, the same period when the virus is most active in the brain.

As we described in Results, the CMV promoter (Boshart et al., 1985) works well to drive GFP expression in all neurons transfected in vitro with a GFP-containing plasmid DNA and generates brightly labeled cells. In contrast, in the transgenic mice with the same CMV promoter sequence, GFP expression was highly localized to specific neuronal groups, indicating the same CMV promoter sequence acted differently in transgenic and transfected neurons.

Different sequences of the CMV promoter have been used previously with a lac $\mathrm{Z}$ reporter with a nuclear localization site (Koedood et al., 1995; Fritschy et al., 1996). Because of the nuclear localization and necessity of staining with a suitable colorant such as X-gal, those mice were less suitable for studies of living neurons than the GFP mice we describe here. What is of potential significant interest is that with slight changes in the CMV promoter sequence, many of the cells that express the reporter gene are quite different. For instance, previously with a -524 to +13 human CMV promoter, expression was found in the mitral cells of the olfactory bulb, retina, CA1 region of the hippocampus, and the granule cells of the cerebellum (Fritschy et al., 1996). In contrast, in the transgenic mice described here with a -583 to $+7 \mathrm{CMV}$ promoter sequence, we found no expression in any of these cells but did find expression in other cells in the same areas. We found little retinal expression. In the olfactory bulb, we found no labeled excitatory mitral cells but did find many labeled inhibitory granule and juxtaglomerular cells. In the hippocampus, we found no labeled CA1 cells but did find some CA3 labeling. In the cerebellar cortex, we found no labeled cells at all but found striking expression in a subpopulation of mossy fibers that originate outside the cerebellar cortex and terminate in the granule cell region. We also found weak expression in the striatum in which no expression was found with the -524 to +13 CMV promoter sequence used by Fritschy et al. (1996).

It might be argued that the difference between the studies is simply because of the random site of integration into chromosomes. This, however, seems less likely, because in our study we generated two independent transgenic lines, made with the same CMV promoter sequence, that showed almost identical sites of expression in the CNS. Similarly, in a previous study with the CMV promoter (Kothary et al., 1991), two different transgenic lines expressed a reporter gene in the same regions of the mice in that study but different from the loci expressing in our mice. Koedood et al. (1995) also reported that transgenic mice with -524 to +13 of the CMV promoter showed patterns of expression that were similar in all three lines studied; similar to other investigators, they found the total levels of expression varied between lines, possibly related to different sites of integration. The difference in loci of expression could also be attributable to differences in the mouse strains used; however, we started out with a cross between two pigmented strains to generate the founder transgenic mice, and when we outcrossed these to albino mice, the loci of expression remained the same, suggesting that strain differences do not easily account for substantial differences. Furthermore, we used C57B mice as part of our initial strain, similar to Kothary et al. (1991). Kothary found expression in muscles and retina and little in brain, whereas we found strong expression in some brain regions and little in retina or muscle.

In three transgenic mouse lines with lac $\mathrm{Z}$ expression, under control of -670 to +54 human CMV promoter, tissue distribution was similar between the three lines (Baskar et al., 1996). Tissue expression of lac Z, not limited to the brain, was also found to be similar to each other in two transgenic mice with a -302 to +72 CMV promoter (Kothary et al., 1991). That different regions of the CMV promoter would generate different patterns of expression in CNS neurons is consistent with the complexity of the CMV promoter that contains binding sites for cAMP, CREB/ ATF, NF-KB, SP1, YY1, retinoic acid, AP-1, NF1, methylation, and its own immediate early protein product (Ghazal et al., 1988, 1992; Hunninghake et al., 1989; Meier and Stinski, 1996, 1997; Mocarski et al., 1996; Prosch et al., 1996).

Another approach to generating transgenic mice in subpopulations of neurons is to use promoters that are specific for substances expressed in subtypes of neurons, such as a neurotrans- 
mitter or its synthetic enzymes (Liu et al., 1997). This approach has been used and should also prove useful. However, the level of expression in positive cells may not be as high as with the CMV promoter, and transmitter promoters may be expressed by cells normally not using a particular transmitter, as described for lac $\mathrm{Z}$ expression under control of the $5^{\prime}$ regulatory region of the glutamate decarboxylase-67 promoter in non-GABAergic excitatory neurons (Sekerkova et al., 1997).

\section{REFERENCES}

Alonso JR, Arevalo R, Porteros A, Binon JG, Lara J, Aijon J (1993) Calbindin D-28K and NADPH-diaphorase activity are localized in different populations of periglomerular cells in the rat olfactory bulb. J Chem Neuroanat 6:1-6.

Baskar JF, Smith PP, Nilvar G, Jupp RA, Hoffmann S, Peffer NJ, Tenney DJ, Colberg-Poley AM, Ghazal P, Nelson JA (1996) The enhancer domain of the human cytomegalovirus major immediate-early promoter determines cell type-specific expression in transgenic mice. J Virol 70:3207-3214.

Boshart M, Weber F, Jahn G, Dorsch-Hasler K, Fleckenstein B, Schaffner W (1985) A very strong enhancer is located upstream of an immediate early gene of human cytomegalovirus. Cell 41:521-530.

Chalfie M (1995) Green fluorescent protein. Photochem Photobiol 62:651-656.

Chalfie M, Tu Y, Euskirchen G, Ward WW, Prasher DC (1994) Green fluorescent protein as a marker for gene expression. Science 263:802-805.

Forss-Petter S, Danielson PE, Catsicas S, Battenberg E, Price J, Nerenberg M, Sutcliffe JG (1990) Transgenic mice expressing betagalactosidase in mature neurons under neuron-specific enolase promoter control. Neuron 5:187-197.

Fritschy JM, Brandner S, Aguzzi A, Koedood M, Luscher B, Mitchell PJ (1996) Brain cell type specificity and gliosis-induced activation of the human cytomegalovirus immediate-early promoter in transgenic mice. J Neurosci 16:2275-2282.

Ghazal P, Lubon H, Heninghausen L (1988) Specific interactions between transcription factors and the promoter-regulatory region of the human cytomegalovirus major immediate-early gene. J Virol 62:1076-1079.

Ghazal P, DeMattei C, Giulietti E, Kliewer SA, Umesono K, Evans RM (1992) Retinoic acid receptors initiate induction of the cytomegalovirus enhancer in embryonal cells. Proc Natl Acad Sci USA 89:7630-7634.

Goodman CS, Spitzer NC (1979) Embryonic development of identified neurons: differentiation from neuroblast to neurone. Nature 280:208-214.

Gustincich S, Feigenspan A, Wu DK, Koopman LJ, Ravioli E (1997) Control of dopamine release in the retina: a transgenic approach to neural networks. Neuron 18:723-736.

Heim R, Tsien RY (1996) Engineering green fluorescent protein for improved brightness, long wavelength, and fluorescent resonance energy transfer. Curr Biol 6:178-182.

Ho M (1991) Cytomegalovirus biology and infection, pp 1-440. New York: Plenum.

Horikawa K, Armstrong WE (1988) A versatile means of intracellular labeling: injection of biocytin and its detection with avidin conjugates. J Neurosci Methods 25:1-11.

Hunninghake GW, Monick MM, Liu B, Stinski MF (1989) The promoter-regulatory region of the major immediate-early gene of human cytomegalovirus responds to T-lymphocyte stimulation and contains functional cyclic AMP-response elements. J Virol 63:3026-3033.

Jankovski A, Sotelo C (1996) Subventricular zone-olfactory bulb migratory pathway in the adult mouse: cellular composition and specificity as determined by heterochronic and heterotopic transplantation. J Comp Neurol 371:376-396.

Keshishian H, Bentley D (1983) Embryogenesis of peripheral nerve pathways in grasshopper legs. I. The initial nerve pathway to the CNS. Dev Biol 96:89-102.

Koedood M, Fichtel A, Meier P, Mitchell PJ (1995) Human cytomegalovirus (CMV) immediate-early enhancer/promoter specificity during embryogenesis defines target tissue of congenital HCMV infection. J Virol 69:2194-2207.
Kothary R, Barton SC, Franz T, Norris ML, Hettle S, Surani MA (1991) Unusual cell specific expression of a major human cytomegalovirus immediate early gene promoter-lac $\mathrm{Z}$ hybrid gene in transgenic mouse embryos. Mech Dev 35:25-31.

Liljelund P, Ghosh P, van den Pol AN (1994) Expression of the neural axon adhesion molecule $\mathrm{L} 1$ in the developing and adult rat brain. $\mathrm{J}$ Biol Chem 269:32886-32895.

Liu J, Merlie JP, Todd RD, O'Malley KL (1997) Identification of cell type-specific promoter elements associated with the rat tyrosine hydroxylase gene using transgenic founder analysis. Mol Brain Res 50 $33-42$.

Lo DC, McAllister AK, Katz LC (1994) Neuronal transfection in brain slices using particle-mediated gene transfer. Neuron 13:1263-1268.

Marshall J, Molloy R, Moss GWJ, Howe JR, Hughes TE (1995) The jellyfish green fluorescent protein: a new tool for studying ion channel expression and function. Neuron 14:211-215.

Meier JL, Stinski MF (1996) Regulation of human cytomegalovirus immediate-early gene expression. Intervirology 39:331-342.

Meier JL, Stinski MF (1997) Effect of a modulator deletion on transcription of the human cytomegalovirus major immediate-early genes in infected undifferentiated and differentiated cells. J Virol 71:1246-1255.

Mocarski ES, Kemble GW, Lyle JM, Greaves RF (1996) A deletion mutant in the human cytomegalovirus gene encoding IE $1_{491 \text { aa }}$ is replication defective due to a failure in autoregulation. Proc Natl Acad Sci USA 93:11321-11326.

Mori K (1987) Membrane and synaptic properties of identified neurons in the olfactory bulb. Prog Neurobiol 29:275-320.

Moriyoshi K, Richards LJ, Akazawa C, O'Leary DDM, Nakanishi S (1996) Labeling neural cells using adenoviral gene transfer of membrane target GFP. Neuron 16:255-260.

Nelson JA, Reynolds-Kohler C, Oldstone MBA, Wiley CA (1988) HIV and HCMV coinfect brain cells in patients with AIDS. Virology 165:286-290.

Paradies MA, Grishkat H, Smeyne RJ, Oberdick J, Morgan JI, Eisenman LM (1996) Correspondence between L7-lacZ-expressing Purkinje cells and labeled olivocerebellar fibers during late embryogenesis in the mouse. J Comp Neurol 374:451-466.

Perlman JA, Argyle C (1992) Lethal cytomegalovirus infection in preterm infants: clinical, radiological, neurological findings. Ann Neurol 31:64-68.

Prosch S, Stein J, Staak K, Liebenthal C, Volk HD, Kruger DH (1996) Inactivation of the very strong HCMV immediate early promoter by DNA CpG methylation in vitro. Biol Chem Hoppe Seyler 377:195-201.

Rakic P (1979) Genetic and epigenetic determinants of local neuronal circuits in the mammalian central nervous system. In: The neurosciences, Fourth Study Program, pp 109-127. Cambridge, MA: MIT.

Saigal S, Lunyk O, Larke RPB, Chernesky MA (1982) The outcome in children with congenital cytomegalovirus infection. Am J Dis Child 136:896-901.

Sanides-Kohlrausch C, Wahle P (1990) VIP and PHI immunoreactivity in olfactory centers of the adult cat. J Comp Neurol 294:325-339.

Sekerkova G, Katarova Z, Joo F, Wolff JR, Prodan S, Szabo G (1997) Visualization of beta-galactosidase by enzyme and immunohistochemistry in the olfactory bulb of transgenic mice carrying lacZ transgene. J Histochem Cytochem 45:1147-1155.

Shepherd GM, Greer CA (1990) The olfactory bulb. In: Synaptic organization of the brain (Shepherd G, ed), pp 133-169. New York: Oxford UP.

Shipley MT, McLean JH, Ennis M (1995) Olfactory system. In: The rat nervous system (Paxinos G, ed), pp 899-926. San Diego: Academic.

van den Pol AN (1985) Silver-intensified gold and peroxidase as dual ultrastructural immunolabels for pre- and postsynaptic neurotransmitters. Science 228:332-335.

van den Pol AN, Kogelman L, Ghosh P, Liljelund P, Blackstone C (1994) Developmental regulation of the hypothalamic glutamate receptor mGluR1. J Neurosci 14:3816-3834.

Wiley CA, Nelson JA (1988) Role of human immunodeficiency virus and cytomegalovirus in AIDS encephalitis. Am J Pathol 133:73-81.

Yang TT, Cheng L, Kain SR (1996) Optimized codon usage and chromophore mutations provide enhanced sensitivity with green fluorescent protein. Nucleic Acids Res 24:4592-4593. 